\title{
Antimicrobial activity of serial extracts from of Aeglemarmelos(linn.) Against dysenteric causing gram negative organisms
}

\author{
Manojkumar.K ${ }^{1}$, seema ${ }^{2}$ \\ 1( Department of Microbiology, Baba Haridass College of pharmacy and technology / Board of Technical \\ Education New delhi / India.) \\ 2 (Department of Microbiology, Baba Haridass College of pharmacy and technology / Board of Technical \\ Education New delhi / India.)
}

\begin{abstract}
The in vitro antimicrobial activity of methanol extracts from Leaves, stream, bark, fruit of Aeglemarmeloswere investigated against bacterial and fungal species. All the extracts exhibitedbroad spectrum antimicrobial activity with zones of inhibition ranging from 10 to $22 \mathrm{~mm}$ against bacteriashigelladysenteriae, shigellaflexneri, vibrio cholerae, vibrio parahaemolyticus, Escherichia coli, salmonella typhi, The minimal inhibitory concentrations $(M I C)$ and the minimal microbicidal concentrations(MMC) of the extracts ranged from 1.25 to $10 \mathrm{mg} / \mathrm{mL}$ and 2.5 to $20 \mathrm{mg} / \mathrm{mL}$ respectively. Assessment of antibacterial efficacy of different extract revealed that The ability of the leaf extracts of Aeglemarmelosto inhibit growth of bacteria and fungi isan indication of its broad spectrum antimicrobial activity which could be a potential source for development ofnovel bioactive antimicrobial agents.
\end{abstract}

Key words :Aeglemarmelos, antimicrobial activity, phytochemicals, serial extracts

\section{Introduction}

The continued emergence or persistence of drug resistant organisms and the increasing evolutionaryadaptations by pathogenic organisms to commonly used antimicrobials have reduced theefficacy of antimicrobial agents currently in use. In addition to this, antibiotics are associated with adverse effects, therefore, the search for new drugs from novel sources, such as plants, is necessary. Ithas been pointed out that more than $80 \%$ of worldis population depends on plants to meet their primary health care needs (1). Plants continue to be a major source of commercially consumed drugs. Even many synthetic drugs have their origin from natural plant products. The trend of using natural products has increased in recent years and the active plant extracts are frequently screened for new drug discoveries (2). Aeglemarmelos(Linn.) belongs to family Rutaceae, commonly known as bael (Hindi) and golden apple (English). It is found throughout India and is known from pre-historic time. Aeglemarmeloshas been used from time immemorial in traditional systems of medicine for relieving constipation, diarrhoea, dysentery, peptic ulcer and respiratory infections (3). Several studies on differentparts of Aeglemarmelosshowed that the plant possesses antidiarrhoeal (4), antidiabetic (5),anti-inflammatory, antipyretic, analgesic (6), anticancer (7), radioprotective (8) and antimicrobial activities $(9,10)$. Limited information is available regarding antimicrobial activity of Aeglemarmelosleaves; therefore, present study is carried out to investigate antimicrobial activity of serial extracts from leaves of Aeglemarmelosagainst various bacterial and fungal species. Preliminary phytochemical studies of these extracts are also undertaken to find out bioactive compounds having antimicrobial activity.

\subsection{Plant material}

\section{Materials and methods}

The leaves of Aeglemarmeloswere collectedfrom their natural habitat from Delhi India.

\subsection{Preparation of extract}

The shade dried leaves bark and fruit were powdered using amechanical grinder and passed through 40 meshsieve. Powder $(300 \mathrm{~g})$ was successively extractedwith $1.5 \mathrm{~L}$, chloroform in a Soxhlet apparatus at $60 \mathrm{n} 70^{\circ} \mathrm{C}$ eachfor $10 \mathrm{n} 12 \mathrm{~h}$ consecutively. Solvents used were ofanalytical grade and removed from all the threeextracts under vacuum and a semisolid mass wasobtained. Extracts were stored in sterile ambercolored storage vials in refrigerator until used forexperiment. 


\subsection{Formulation of extract}

Each extract was dissolved in 20\% dimethylsulfoxide (DMSO) treated water and sterilized bypassing through membrane filter of $0.2 \mu \mathrm{m}$ pore sizebefore antimicrobial testing.

\subsection{Test microorganisms}

Bacterial and fungal isolates used in the present study (bacteriashigelladysenteriae,,shigellaflexneri, vibriocholeravibrio parahaemolyticus, Escherichia coli, Salmonella typhi, were obtained from HiMedia Laboratories Pvt. Ltd. Navi Mumbai, culture collections of microbiology departments of All India Institute of Medical Sciences, New Delhi. The bacterial isolates were first subcultured in a nutrient broth and incubated at $37^{0} \mathrm{C}$ for $18 \mathrm{~h}$.

\subsection{Antimicrobial activity}

The antimicrobial sensitivity patterns for the extracts were studied by disc diffusion method (13). Sterile discs $(6 \mathrm{~mm})$ prepared from Whatmanis filter paper no. 1 were made to absorb $(500 \mu \mathrm{g})$ of the test samples. Discs were left to dry under laminar flow cabinet overnight. Standard reference antimicrobial discs with ofloxicine ,ciprofloxicine $(30 \mu \mathrm{g})$ for bacteria were used as positive control and solvent discs were used as negative control. The microbial isolates were first grown in a nutrient broth for $18 \mathrm{~h}$ before use and standardized to $0.5 \mathrm{McF}$ arland standards $(1.5 \diamond 108 \mathrm{cfu} / \mathrm{mL})$. Mueller-Hinton agar was prepared on the plates as the medium for the test organism. The microbial inoculum was spread evenly onto the surface of agar plate using the sterile cotton bud and then the extracts discs, 20\% DMSO impregnated discs and standard antimicrobial discs were positioned on the inoculums agar surface. The antimicrobial activity was interpreted from the size of diameter of zone of inhibition measured to the nearest $\mathrm{mm}$ as observed from clear zone surrounding the disc. Each plant part extract was assayed in triplicate and the mean of the three values was taken and the pyto chemical study were tabulated in TABLE 3.

\subsection{Determination of minimal inhibitory concentration(MIC)}

The minimal inhibitory concentrations of different extracts were determined by twofold serial micro dilution method using sterile 96 well microliter plates (14). Hundred microliters of the test extracts at a final concentration ranging from 10 to $0.0049 \mathrm{mg} / \mathrm{mL}$ were introduced into the wells before $100 \mu \mathrm{L}$ of standardized cell suspensions were added in each well. Microbial suspensions were used as a positive control and extract in broth was used as negative control. The MIC was taken as the lowest concentration of the extract in the well of microtitre plate that showed no turbidity after $24 \mathrm{~h}$ of incubation at $37^{\circ} \mathrm{C}$. The turbidity of the wells was interpreted as the visible growth of microorganism.

\subsection{Determination of minimal microbial concentration (MMC)}

The MMC of the extracts was determined by a modification of the method of Spencer and Spencer (15). Samples were taken from plates with no visible growth in the MIC assay and subcultured on freshly prepared nutrient agar plates, later incubated at $37^{\circ} \mathrm{C}$ for $48 \mathrm{~h}$ for bacteria. MMC was taken as the concentration of the extract that did not show any visible growth on new set of agar plates.

\subsection{Antibacterial activity}

\section{Results}

All the various parts of plant extracts showed varying degree of antibacterial activity against the test organisms (TABLE 1).

Disc diffusion assay revealed maximum inhibition zones against Gram negative organisms shigelladysenteriae, shigellaflexneri vibrio choleraevibrio parahaemolyticus,Salmonella typhi, and Escherichia coli . chloroform leaves extract suggesting the highest antibacterial efficacy of other plant part extract against these organisms. Further, it compared favorably with standard antibacterial drug o-floxicine. Antibacterial activity of bark extract was moderateagainst V.choleraand mild against Salmonella typhi. E.colishowed maximal zone of inhibition with chloroform extract suggesting highantibacterial efficacy of leaf extract against these organisms. Further, it compared favorably with o-floxicine. The antibacterial activities of leaf extract were moderate against v.choleraand Escherichia coli and were mildagainstSalmonella typhi.bark extract showed maximum zone of inhibition against Salmonellatyphisuggesting highest efficacy against this organism. Further, it compared favorably with cefuroxime. The antibacterial activities of methanol extract were mild against the rest of the tested microorganisms.

The MIC of different extracts ranged from 1.25 to $10 \mathrm{mg} / \mathrm{mL}$ and are shown in TABLE 2.The MIC shigellaspecious organisms were the lowest with bark and fruit extract suggesting that the smallest amount of this extract was required and was most potent. Also the MIC for control cefuroxime ranged from 0.0195 to $0.0391 \mathrm{mg} / \mathrm{mL}$. The MIC for vibrio specious werethe lowest with fruit and bark extract suggesting that the 
smallest amount of bark extract was required and was most potent. Also the MIC for control cefuroxime ranged from 0.0391 to $0.078 \mathrm{mg} / \mathrm{mL}$. The MIC for Salmonella typhiwas the lowest with leaf extract suggesting that the smallest amount of this extract was required and was most potent. The MIC of the standard drug cefuroximewas $0.078 \mathrm{mg} / \mathrm{mL}$. The MMC of the petroleum ether, chloroform and methanol extracts for differentbacteria ranged from 2.5 to $20 \mathrm{mg} / \mathrm{mL}$.

\section{Discussion}

Aeglemarmelosleaf extracts showed varying degree of broad spectrum antimicrobial activities against tested bacterial species. Antimicrobial activities of leaf , bark and fruit extracts could be attributed to the presence of phenols and sterols as such activities withthese compounds are reported [16, 17]. The antimicrobial activities of leaf extract may be due to the presence of tannins, triterpenoids and flavonoids. Tannins have been known to form irreversible complexes withprolene rich protein resulting in the inhibition of cell wall synthesis [18]. Triterpenoids are known to weaken the membranous tissue, which results in dissolving cell wall of microorganism [19]. Flavonoids, another constituentof methanolleaf extract, have exhibited a large number of biological activities like anti-inflammatory, antioxidant and antimicrobial properties [20]. Antifungal activity exhibited by methanol extracts of Aeglemarmelosleaves against all tested organisms be contributed due to the presence of coumarins. components of these extracts that showed these effects were not identified, yet the positive presence of antimicrobial active principles such as phenols, sterols, flavonoids, tannins, triterpenoids and coumarins seems to cause these activities. The ability of the leaf extracts of Aeglemarmelosto inhibit growth of bacteria is an indication of its broad spectrum antimicrobial activity, which may be employed as a source to develop new antimicrobialagents.

Table1. Antimicrobial activity of serial extracts from leaves bark and fruit of Aeglemarmelos

\begin{tabular}{|l|c|l|l|}
\hline \multirow{2}{*}{ Test micro organisms } & \multicolumn{2}{|l|}{ Zone of inhibition $(\mathrm{mm})($ the mean $\pm \square \mathrm{SD})$} \\
\cline { 2 - 4 } & Leafextract $(500 \mu \mathrm{g} / \mathrm{mL})$ & Barkextract $(500 \mu \mathrm{g} / \mathrm{mL})$ & Fruitextract $(500 \mu \mathrm{g} / \mathrm{mL})$ \\
\hline shigelladysenteriae & $16 \pm 0.4$ & $10 \pm 0.2$ & $4 \pm 0.4$ \\
\hline shigellaflexneri & $18 \pm 0.8$ & $11 \pm 0.2$ & $5 \pm 0.5$ \\
\hline vibrio cholerae & $16 \pm 0.5$ & $9 \pm 0.7$ & $6 \pm 0.2$ \\
\hline vibrio parahaemolyticus & $15 \pm 0.2$ & $8 \pm 0.2$ & $4 \pm 0.5$ \\
\hline Salmonella typhi & $12 \pm 0.6$ & $7 \pm 0.4$ & $4 \pm 0.3$ \\
\hline Escherichia coli & $11 \pm 0.3$ & $9 \pm 0.4$ & $5 \pm 0.6$ \\
\hline
\end{tabular}

Table 2.MIC and MMC values of extracts from leaves of Aeglemarmelosand standard drugs in mg/mL.

\begin{tabular}{|l|l|l|l|l|l|l|l|l|}
\hline \multirow{2}{*}{ Test organisms } & Leaf extract & \multicolumn{2}{l|}{ Barkextract } & Fruitextract & Ofloxicine & ciprofloxicine \\
\cline { 2 - 10 } & MIC & MMC & MIC & MMC & MIC & MMC & MIC & MIC \\
\hline shigelladysenteriae & 5 & 20 & 10 & 20 & 10 & 10 & 0.0391 & 0.0098 \\
\hline shigellaflexneri & 5 & 10 & 10 & 20 & 5 & 2.5 & 0.0195 & 0.0049 \\
\hline vibrio cholerae & 10 & 20 & 1.25 & 2.5 & 1.25 & 2.5 & 0.0195 & 0.0098 \\
\hline $\begin{array}{l}\text { vibrio } \\
\text { parahaemolyticus }\end{array}$ & 5 & 10 & 5 & 10 & 5 & 5 & 0.0391 & 0.0098 \\
\hline Salmonella typhi & 1.25 & 2.5 & 2.5 & 5 & 1.25 & 2.5 & 0.0391 & 0.0049 \\
\hline Escherichia coli & 1.25 & 2.5 & 1.25 & 2.5 & 2.5 & 2.5 & 0.0391 & - \\
\hline
\end{tabular}

$\mathrm{MIC}=$ minimum inhibitory concentration; $\mathrm{MMC}=$ minimum microbicidal concentration.

Table 3.Phytochemical screening of serial extracts from Aeglemarmelos.

\begin{tabular}{|l|l|l|l|}
\hline Phyto chemical & Leaf extract & Bark extract & Fruit extract \\
\hline Tannins & - & - & + \\
\hline Flavonoids & - & - & + \\
\hline Saponins & - & - & + \\
\hline Phenols & + & + & + \\
\hline Coumarins & - & - & + \\
\hline Sterols & + & + & + \\
\hline Triterpenoids & - & - & + \\
\hline
\end{tabular}

$(+)$ present; (n) absent 


\section{References}

[1] WHO Traditional medicine: Growing needs andpotential, WHO Policy perspectives on medicines. World HealhOrganisation, Geneva 2002.

[2] Ncube N.S., Afolayan A.J., Okoh A.: Afr. J.Biotechnol. 7, 1797 (2008).

[3] (Nadkarni A. K.)Indian MateriaMedica, $3^{\text {rd }}$ edn p. 45( PopularPrakashan Private Ltd.,Mumbai 2000).

[4] Shobha F.G., Thomas M.J. Ethnopharmacol.76, 73 (2001).

[5] Veerappan A., Shigeru M., Renganathan D.J.Ethonopharmacol. 96, 159 (2005).

[6] Lotufu L.V., Khan M.T., Ather A., Wilke D.V.,Simenez P.C. et al.: J. Ethonopharmacol. 99,21 (2005).

[7] Jagetia G.C., Venkatesh P., Balinga M.S.: Int. J. Radiat. Biol. 80, 281 (2004)

[8] Rana B.K., Jain A.K.: J. Ethnopharmacol. 57, 29 (1997).

[9] Rani P., Khullar N.: Phytother. Res. 18, 670 (2004).

[10] Trease G.,E., Evans W.C.: Textbook ofPharmacognosy12th edn. Balliere, Tindall, London 1989.

[11] (Harborne J. B).:Phytochemical Methods $n$ A Guide to Modern Techniques of Plant Analysis (Chapman and Hall, London 1998.)

[12] Bauer A.W., Kirby W.M., Sherris J.C., Turck M.: Am. J. Clin. Pathol. 45, 493 (1966)

[13] (Isenberg H.D)Essential Procedures for Clinical Microbiologyp. 216( American Society forMicrobiology, Washington DC 1998.)

[14] (Spencer A.L.R., Spencer J.F.T) Public Health Microbiology:Methods and Protocols p. 325(HumanaPress Inc., New Jersey 2004.)

[15] Zhu X., Zhang H. Lo R.: J. Agric. Food Chem. 52, 7272( 2004).

[16] Chidambara K.N., Murthy A., Vanitha M.,Swamy M.,Ravishankar G.A.: J. Med. Food 6,99 (2003).

[17] Shimada T.: J. Chem. Ecol. 32, 1149 (2006).

[18] Mamtha B., Kavitha K., Srinivasan K.K., Shivananda P.G.: Indian J. Pharmacol. 36, 401 (2004).

[19] Hemandez N.E., Tereschuk M.L., Abdala L.R.: J. Ethnopharmacol. 73, 317(2000)

[20] Ojala T., Remes S., Haansuu P., Vuorella H., Hiltunen R.et al.: J. Ethnopharmacol. 73, 299 (2000). 